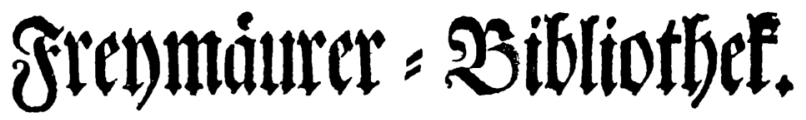

\section{Siebentes Stút.}

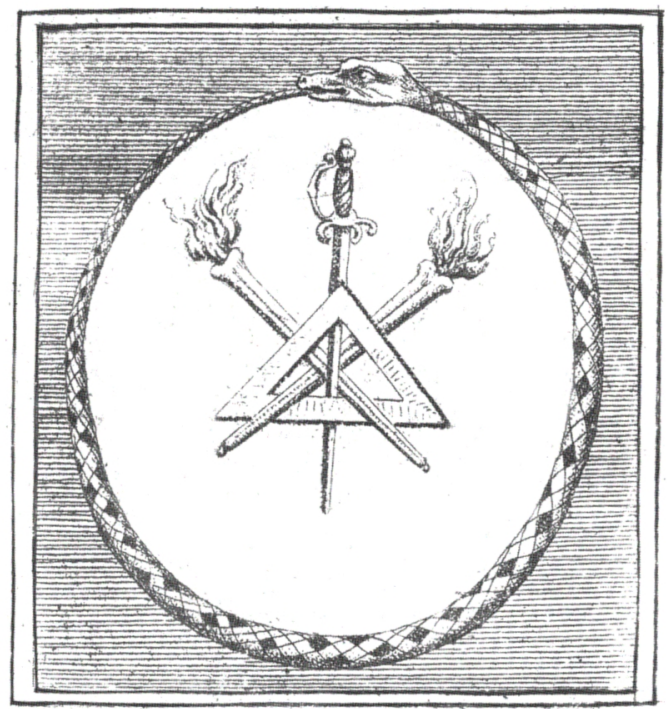

Berlin, 1794.

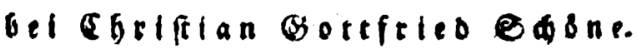


